\title{
Stand-Alone Photovoltaic System to Mitigate Pollution in Bodies of Water CASE Study: Laguna Del Carpintero, Tampico, Tamaulipas
}

\author{
Adán Hernández-Sánchez, Josefina García-Navarro, María Esther Bautista-Vargas, \\ Santiago Gómez-Carpizo, Raúl Hernández-Martínez
}

Academic Program in Energy Engineering, Universidad Politécnica de Altamira, Altamira, México

Email: esther.bautista@upalt.edu.mx

Received 13 March 2015; accepted 17 April 2015; published 20 April 2015

Copyright (C) 2015 by authors and Scientific Research Publishing Inc.

This work is licensed under the Creative Commons Attribution International License (CC BY). http://creativecommons.org/licenses/by/4.0/

(c) (i) Open Access

\section{Abstract}

One of the main environmental issues at present times is the pollution of hydrological resources. Water quality is a major factor to ecosystems, mostly those that support human health, food production and biodiversity. The utilization of renewable energy sources as solar energy through Photovoltaic Cells is a competitive and consolidated option to approach the solution of this kind of issues. This document is intended to introduce a prototype powered by photovoltaic cells to aerate a body of water and increase the amount of Dissolved Oxygen (DO) in water. The body of water studied is the lagoon Laguna del Carpintero in Tampico, Tamaulipas, Mexico. A Stand-alone Photovoltaic System (SPS) prototype was designed for this matter with the purpose of powering a pumping system to sprinkle water to the lake's surface. This system is a way of ventilating the water so that it gets in direct contact with the surrounding atmosphere obtaining mean values compared to prevailing values of DO contained in the lagoon. We obtained DO concentration values going from 7 to $8 \mathrm{mg} / \mathrm{L} \mathrm{of} \mathrm{O}_{2}$ in different tests which can be considered an appropriate parameter for this body of water. The efficiency of the SPS was proved as it showed good performance by supplying power to the oxygenation system compared to the dimensional estimate. Improving the SPS prototype is the main goal of this work so that this oxygenation system could be used in other urban lagoons in the surrounding area without being powered by electrical grid. This makes possible to locate it at any point of the body of water to mitigate the pollution by increasing the amount of DO.

\section{Keywords}

Photovoltaic System, Pollution, Water Aeration, Bodies of Water, Laguna de Carpintero 


\section{Introduction}

Wetlands are present in a variability of environments. They contain a diversity of ecosystems that differ mainly in their grade of humidity or flooding so the quantity, quality and seasonality are the environmental factors that determine them [1]. Currently, one of the environmental capital problems is the pollution of hydrological resources, due to the variability of sources like nutrient flow, origin of water, supplying mechanism, local disruptions and human activities produced in wetlands i.e. the quality status of the water implies the expected use for it and the concept of water pollution infers to its subsequent use [1] [2].

One of the aspects that demonstrate the level of contamination in a body of water is the water quality which is measured by chemical, physical, biological and toxicological indicators. Temperature, thermal conductivity, salinity and dissolved oxygen (DO) are the basic parameters to stablish a manner to catalogue the possible factors for the health of an aquatic ecosystem [3] [4]. This is an important measure in connection to requirements of one or more biotic species or any human need or purpose [5]. Other parameters are total dissolved solids (TDS), heavy metals, pathogens and organic compounds. These indicators show the permissible ranges in order to assess water quality and are related to ecosystem health, safety of human contact and drinking water. It is used most frequently as reference to a set of standards against which compliance can be evaluated [4] [6].

The need for sanitation of water resources is important for natural ecosystems that support human health, food production and biodiversity. In 2010, 79\% of the world's urban population had access to improved sanitation, compared with a $47 \%$ for the rural population [6]. Economic losses due to lack of water and sanitation in Africa alone are estimated at 28,400 million dollars (md) [7]. Currently, 96\% of the urban population has access to improved drinking water sources. However, Development Objective Millenniumon sanitation will not be reached by 2015, yet at present times 789 million urban dwellers live in the world without access to improved sanitation. Urban areas have a need for equipment according to population growth [6] [8].

The increase in annual pollution in water bodies is equivalent to the weight of the world's population (about 7000 million people) [7]. Water contamination weakens or destroys the natural ecosystems that support human health, food production and biodiversity. Several studies have estimated that the value of the role which ecosystems perform is twice larger than the Gross Domestic Product of the world economy, and estimated the role that freshwater ecosystems played to purify water and absorb waste exceeds 400,000 million dollars in the USA. Most of contaminated fresh water ends in the oceans, causing damage to coastal areas and fisheries [9]-[11].

Oxygen production is related to gas exchange through the surfaces of bodies of water, plus the photosynthetic production, respiratory consumption and physical processes of advection (horizontal air movement caused mainly by variations in air pressure near the surface) and diffusion [11] [12]. The total concentration of DO depends on the balance between all these phenomena. One alternative to mitigate contamination from lack of oxygen is the use of water aeration system dispersing the liquid in the body surface of water, making direct contact with oxygen in the atmosphere. This requires a pneumatic pump powered for electricity, which has consequences for energy expenditure.

That is why in this paper a prototype of an air pump supplied with Stand-alone Photovoltaic System (SPS) prototype, where I adapted to work efficiently with the conditions of the study area, designed their primary scope is to achieve water circulation body of water, whereby the DO levels and decreased bad smell rise. One of the perspectives of this research is the use of this system in other urban aeration lagoons. The advantage of oxygenation system is its power supply as a type of renewable energy supplies. In this paper it is solar energy functioning autonomously with the solar photovoltaics module [12] [13]. Renewable energies such as solar energy through photovoltaic cells are braced and competitive to solve problems of this type option.

\section{Methodology}

This study conducted during the period 2014-2015 at the Polytechnic University of Altamira, Tamaulipas, Mexico. Measurements of DO levels conducted in the study area in two stages, before and after the prototype SPS at time intervals of 5 hours. The methodology for the determination of DO in the water body was based on the NMX-AA-012-SCFI-2001, which establishes the determination of DO in natural and treated wastewater, waste, showing the test method [14]. To effect of water, aeration prototype used a kind SPS [13], was designed taking into account geographical and climatic conditions of the study area. The results were through sampling and measuring DO levels in the water body in situ comparing current conditions and after the application of the use 
of the prototype.

\subsection{Stage 1: Description of the Studied Zone}

For the southern region of Tamaulipas, Mexico's most important, after the Gulf of Mexico, hydrological element is the Panuco River which it joins the River Tamesí at its end. This region is the area of lakes that make up the Lagunario Guayalejo-Tamesí River System. Wherewaterbodies are located, including gaps Carpintero, El Chairel, La Vega Escondida, Tancol, Champayán, La Puerta, San Andrés, theMarshes, Canyon, San Jaurey, El Gringo, La Aguada Grande, Los Patos, la Ilusión y Nuevo Amanecer [15]. The municipality Tampico, Tamaulipas has an area of $92.73 \mathrm{~km}^{2}$, its total population in 2010 was 297.554 in habitants. Bordered on the north by the state of Veracruz and the municipality of Altamira; on the east by the town of Ciudad Madero and the state of Veracruz; south with state of Veracruz; west with the state of Veracruz [16] [17].

In Figure 1, the body of water where DO sampling was performed and observed the application of SPS prototype. The object of study is the Laguna de Carpenter (LC), which is located at the Panuco River Basin, between $220^{\circ} 15^{\prime}$ and $220^{\circ} 14^{\prime} 33^{\prime \prime}$ north latitude and $970^{\circ} 51^{\prime}$ and $970^{\circ} 52^{\prime}$ west longitude, in the center of the municipality [18]. It has an average length of $2000 \mathrm{~m}$, an average width of $400 \mathrm{~m}$. An area of 90.4 ha and an average depth of $1.2 \mathrm{~m}^{2}$, is surrounded by very important recreational activities in the area, so it is of great benefit to improve water quality, and improving the quality of life of the species in it inhabit.

\subsection{Stage 2: D0 Measurement Methodology}

For the determination of DO, there are two methods: the Winkler and electrometric, for this project the second method is used, because the conditions of the sampling point, it is more feasible to measure with a portable oxygen measurement DO sensitive electrode membrane. The technique used for the determination of DO, is as indicated in the NMX-AA-012-SCFI-2001 [14]. The procedure described by stage of development:

Step 1: Collecting, preserving and storing samples. Avoid the sample is shaken or contact with air. The sample analysis should be performed immediately after collection, so it is not necessary to add any preservatives.

Step 2: Calibration. The zero standardization of DO is the immersion of the electrode in standard solution of zero oxygen concentration. Reading must be zero $\mathrm{mg} / \mathrm{L} \mathrm{DO}$, otherwise, set the instrument to zero. Adjust the instrument to the barometric pressure.

Step 3: Procedure. After calibration of the instrument to proceed to the measurement of the samples follows. Insert the electrode previously washed with water to the sample. Evenly stirring and oxygen concentration read directly from the instrument.

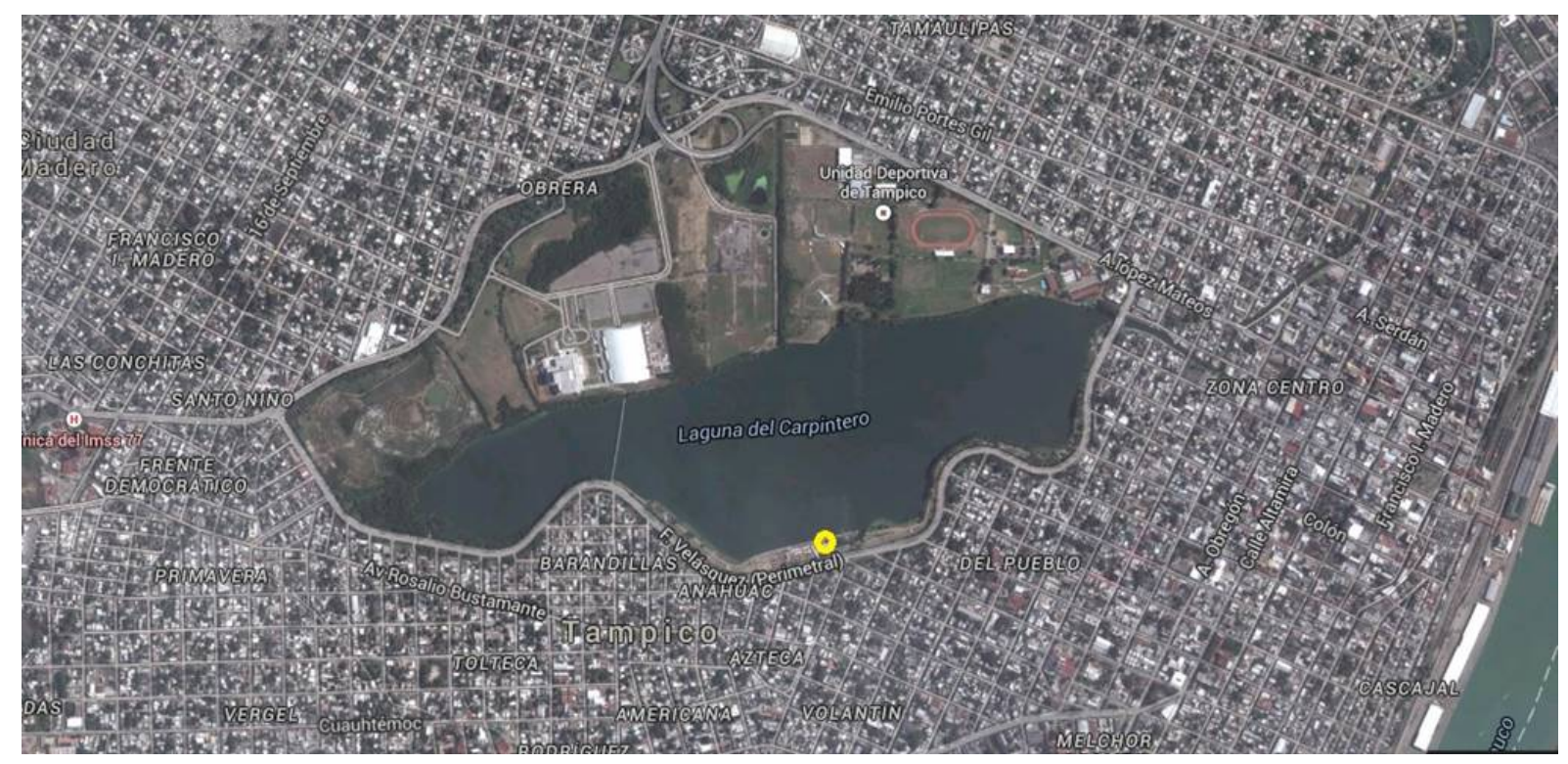

Figure 1. Location of the study area: Laguna de Carpintero, Tampico, Tamaulipas, Mexico. 
Step 4: Calculations. DO concentrations are taken directly from the meter reading DO.

Subsequently, the ranges specified by the Environmental Protection Agency (EPA) regarding the levels of DO concentration and the consequences they represent (Table 1) [19] are used [20]. Allowing comparison with results obtained in the study.

\subsection{Stage 3: Stand-Alone Photovoltaic System (SPS) Prototype Design}

To supply the prototype was used is a SPS. It also may use a hybrid photovoltaic system with the help of an interconnected wind turbine in the system, all this taking into account the conditions of the area such as rush hour sun in the city of Tampico has a $4.5 \mathrm{hr}$, with an inclination of $21.5^{\circ}$ and a wind speed of 2.5 to $3 \mathrm{~m} / \mathrm{s}$ [13]. In Figure 2, the load obtained is provided by a solar photovoltaic module $100 \mathrm{~W}$ to 12 volts, being regulated by an electronic controller cargo with a maximum capacity of $1500 \mathrm{~W}$. All this connection is supplied to a 12 volt battery connected to terminal charge controller is the same as supply sufficient power to the pump that works with a voltage of 12 volts and a current of 1 A with a pumping capacity of $12 \mathrm{~L} / \mathrm{min}$. The water flows through the pump connecting the outlet of this, a wait of water for greater contact of liquid with the ambient air.

\section{Results and Discussion}

The LC was receiver municipal wastewater discharges body for over 20 years, receiving channels of storm spending about $450 \mathrm{~L} / \mathrm{s}$ of water this, nowadays, still occurs due to the silting there to inside the lagoon by perimeter drains and the river channel Cutting [18]. These conditions bring negative consequences DO levels in water, to this aeration was designed water dispersing the liquid on the surface of the LC, making direct contact with oxygen in the atmosphere. This achieved by the suction of a vacuum pump supplied with a photovoltaic system type island calculated to work efficiently with the conditions of the southern region of Tamaulipas; its main scope is to achieve water circulation of the water body. Which DO levels and decreased bad smell rise, this aeration system could use in other urban lakes. The advantage of oxygenation system is its power supply as it's supplied by a type of renewable energy, which in the case of this paper is photovoltaics, which generated using

Table 1. Ranges of DO concentration and its impact on aquatic ecosystems.

\begin{tabular}{ccc}
\hline DO $(\mathrm{mg} / \mathrm{L})$ & Condition & Consequences \\
\hline 0 & Anoxia & Mass death of aerobic organisms \\
$0-5$ & Hypoxia & Disappearance of organisms and sensitive species \\
$5-8$ & Acceptable & Good \\
$8-12$ & Supersaturated & Full photosyntheticproductionsystems \\
\hline
\end{tabular}

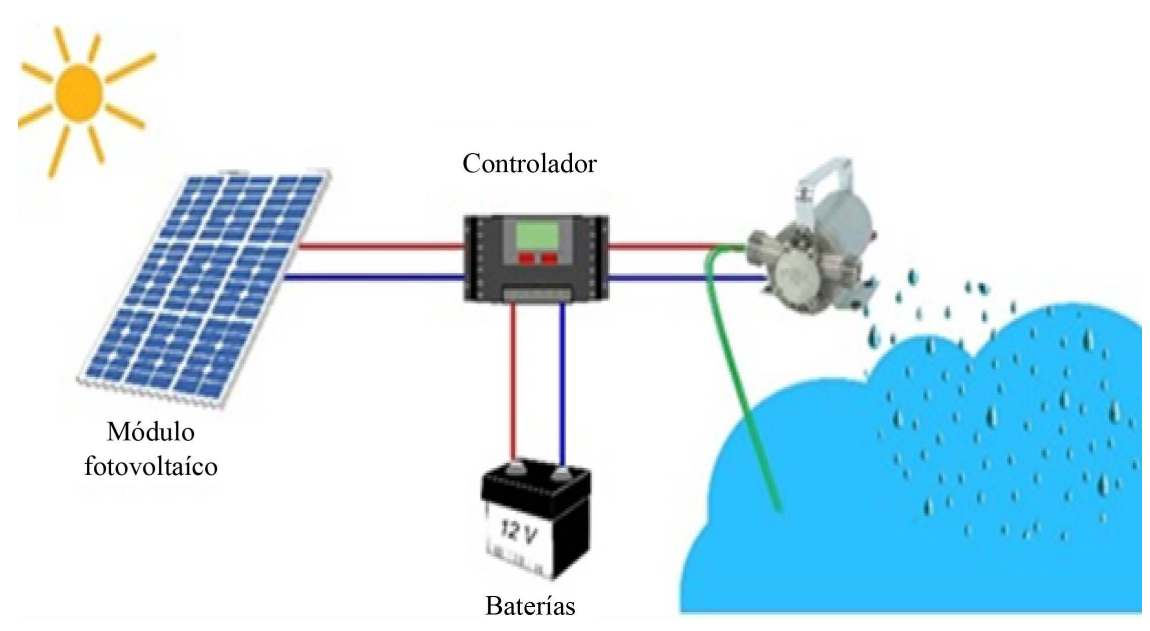

Figure 2. Connection diagram prototype. 
sunlight of the area getting their operation so introducing autonomous solar modules, for feeding the different factors contemplated peak sun hours on, fillers and sizing systems connections [13]. The DO can be expressed in milligrams per liter (mg/L) or saturation percentage (\%). Of the first mass expressed directly oxygen per liter of water options, while the second is expressed as the percentage of the saturation concentration for a given Temperature [11].

To have a knowledge of the conditions of DO in the pond Carpenter, measurements in the water of this parameter is recorded, allowing to compare levels of the analysis intervals established optimal conditions for life to exist aquatic ecosystem LC. DO analyzes were performed with the equipment DO meter (Figure 3), which is a DO meter, these measurements were recorded periodically for increases and decreases in DO levels permissible in the ecosystem.

The results obtained are in Table 2, in which increased DO levels after aeration of the water is observed, also the dependence of the values of this parameter with temperature is observed (Table 3). In the which it was observed that the best time to operate the venting system is in the evenings, when lower DO values, coupled with photosynthesis decreases during the evening, because it also impacts the values are recorded DO [21].

For DO readings, water sampling is necessary to do so in situ, this in order that the sample not be changes in a possible move and get correct information. DO readings are made with the aid of an electrode connected to the DO meter (Figure 4), which has a membrane on the end part of this, this membrane before use. Should undergo cleaning comprising immersing the membrane for 5 minutes in an electrolyte solution. After which time the solution is discarded and refilled to hydrate the membrane of this solution. The next step is to remove the membrane from the solution by connecting the electrode to the computer so that by introducing this in the sample water supply DO existing levels [22].

The data obtained from measurements of DO compared to the permissible parameters, makes us conclude that the levels of this parameter are not suitable for life to develop and consequently the food chain that exists in this

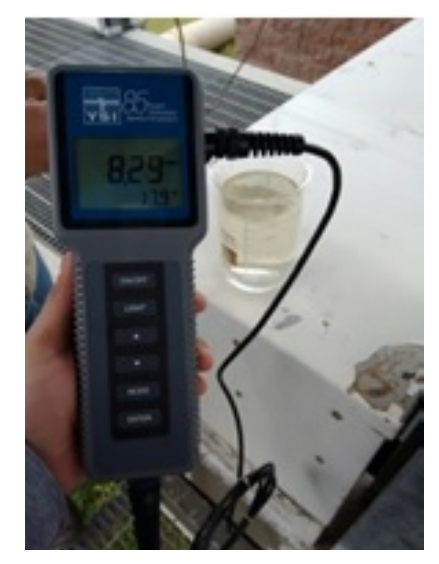

Figure 3. Equipo DO meter.

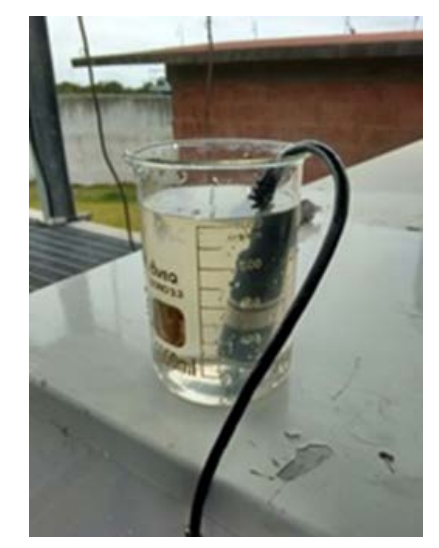

Figure 4. DO meter analysis team. 
Table 2. DO, and Temperature measurements at the sample point.

\begin{tabular}{|c|c|c|c|c|}
\hline \multirow{2}{*}{$\begin{array}{l}\text { Sampling station } \\
\text { Item } 1\end{array}$} & DO (mg/L) & Temperature $\left({ }^{\circ} \mathrm{C}\right)$ & $\mathrm{DO}(\mathrm{mg} / \mathrm{L})$ & Temperature $\left({ }^{\circ} \mathrm{C}\right)$ \\
\hline & \multicolumn{2}{|c|}{ Afteraeration } & \multicolumn{2}{|c|}{ Beforeaeration } \\
\hline 10:00 horas & 6.71 & 16.5 & 8.49 & 16.9 \\
\hline 11:00 horas & 6.44 & 17.7 & 8.29 & 17.9 \\
\hline 12:00 horas & 6.38 & 18.5 & 8.13 & 18.7 \\
\hline 13:00 horas & 6.15 & 20 & 7.31 & 19.6 \\
\hline 14:00 horas & 6.03 & 21 & 7.29 & 21.7 \\
\hline
\end{tabular}

Table 3. Concentration dependence of DO relative to the water temperature.

\begin{tabular}{cccc}
\hline Temperature $\left({ }^{\circ} \mathrm{C}\right)$ & DO $(\mathrm{mg} / \mathrm{L})$ & Temperature $\left({ }^{\circ} \mathrm{C}\right)$ & DO $(\mathrm{mg} / \mathrm{L})$ \\
\hline 0 & 14.16 & 18 & 9.18 \\
1 & 13.77 & 19 & 9.01 \\
2 & 13.40 & 20 & 8.84 \\
3 & 13.05 & 21 & 8.68 \\
4 & 12.70 & 22 & 8.53 \\
5 & 12.37 & 23 & 8.38 \\
6 & 12.06 & 24 & 8.25 \\
7 & 11.76 & 25 & 8.11 \\
8 & 11.47 & 26 & 7.99 \\
9 & 11.19 & 27 & 7.86 \\
10 & 10.92 & 28 & 7.75 \\
11 & 10.67 & 29 & 7.64 \\
12 & 10.43 & 30 & 7.53 \\
13 & 10.20 & 31 & 7.42 \\
15 & 9.98 & 32 & 7.32 \\
17 & 9.76 & 33 & 7.22 \\
\hline
\end{tabular}

ecosystem is broken, resulted fish kills. Therefore, the water aeration was performed with a SPS prototype, which is to pump water with low levels of DO to the atmosphere so as to be vented for periods that are programmed depending on the constant of oxygen present in re-sampling. The water is pumped it is spread on the same body of water leading to drops of water that are pumped with a direct contact with oxygen in the atmosphere and thus acquire oxygen missing at the bottom of the water. Because that in most of the time getting this water is only in the superficial part of the lagoon, while the remaining water from the LC mostly the fund has no contact with the resulting low DO affecting the development of microorganisms necessary for the proper physical and chemical state of the lagoon.

The oxygenation system are powered by the energy provided by a SPS, having a high efficiency electrical parameters of the conditions taking into account the elements that comprise such as the battery. The charge cycle with 2 hours in his 100\%, which conducted efficiently worked. With the results of required voltage (12 Volt) and delivered power (65 W), being also a result of the project. $50 \mathrm{~W}$ being necessary for feeding pump, obtaining a $30 \%$ power than necessary and as an extra factor for not having registered failures in the system discharge [13].

After starting the oxygenation system, were obtained as measurement results of DO values of 7 - 8 mg/L of $\mathrm{O}_{2}$ in the water of the pond in the different samples. These results show favorable DO values implying a suitable condition in the body of water [23]. Registering due to the $\mathrm{DO}$ values in a range of $7 \mathrm{mg} / \mathrm{L}$ to $8 \mathrm{mg} / \mathrm{L} \mathrm{O}$. As a result, water levels are above the low oxygen levels in water bodies and thus living conditions for the development of all species of fish and microorganisms that inhabit the $\mathrm{LC}$ are improved and the reduction of $\mathrm{CO}_{2}$, methane and other volatile organic compounds that are the cause of bad smell.

Figure 5 shows the operating oxygenation system. With which the efficiency of the SPS to reflect the proper 


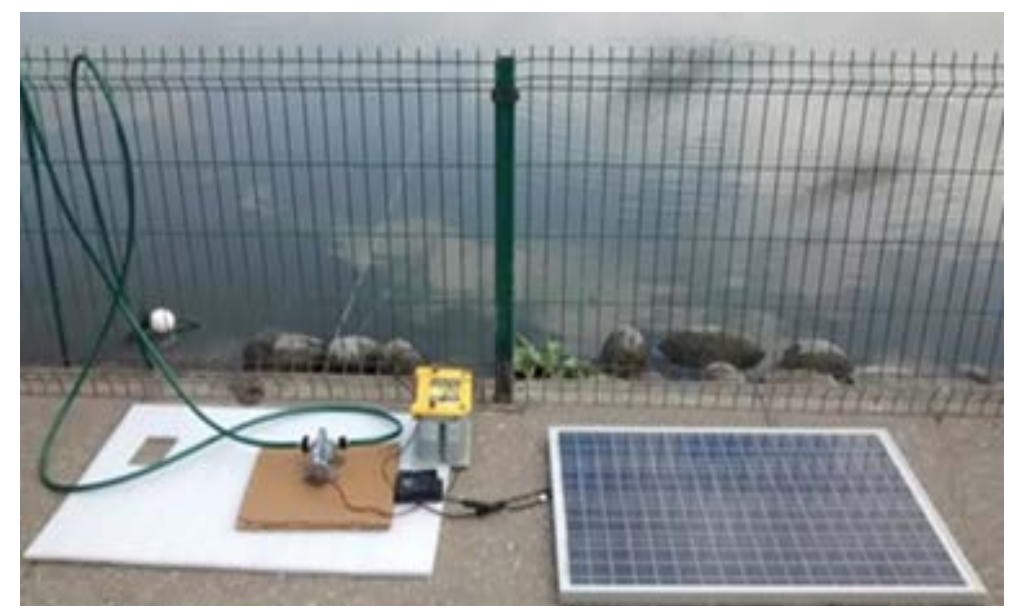

Figure 5. Working prototype SPS.

functioning it had to supply power to the system oxygenation compared with calculations for this to be sized [13] was checked. All independent photovoltaic system interconnection is considered efficient proportions delivering these being compared with those required in our case the system worked properly. Concluding not having registered malfunction, electric shock or excessive consumption of the battery and the voltage supplied by the solar array which was recorded in a range of $90 \%$ efficiency and driver help all conditions were handled correctly, and considering that our element feed worked optimally due that it had the voltage and current required for its proper functioning.

\section{Conclusion}

Existing DO levels in water bodies are classified as water on oxygenation values $>12 \mathrm{mg} / \mathrm{L} \mathrm{O}_{2}$ poor water and oxygen in the range $<5 \mathrm{mg} / \mathrm{l} \mathrm{O}_{2}$, so that the results of DO after use of oxygenation system show that the amount of this parameter is favored in water. This oxygenation system can be used in other urban lakes, without being fed-das by the power grid, making it possible to locate this system at any point of the water body. Lack of DO in the water in the LC, with the use of a system that uses solar energy, which achieves circular water, raising the levels of DO and decreased water odor is resolved. The scope of work is to improve the prototype of SPS, oxygenation system that can be used in other urban lakes, without being fed by the power grid, making it possible to locate this system at any point of the water body in order to mitigate the polluter and raising levels of DO in water.

\section{References}

[1] Ruíz-Maraboto, J.E., Sánchez-Torres, E.G., Cabrera-Cruz, R.B.E., Rolón-Aguilar, J.C. and Pichardo-Ramírez, R. (2014) Retrospective on Water Availability as a Reference to Determine the Water Vulnerability to Climate Change Scenarios in the SLRGT, Tamaulipas, Mexico. Proceedings of the 3rd National Conference on Research on Climate Change: The Future of Research of Climate Change in Mexico of the UNAMPINCC, Tampico, 14-18 October 2013, CDR.

[2] NAWACO (2012) Regional Water Program Vision 2030. Hydrological-Administrative Region IX Northern Gulf. Comision Nacional de Agua. Ed. SEMARNAT, México.

http://www.conagua.gob.mx/conagua07/publicaciones/publicaciones/9-sgp-17-12gn.pdf

[3] Diersing, N. (2009) Water Quality: Frequently Asked Questions. Florida Brooks National Marine Sanctuary, Key West, FL.

[4] NIECC (2009) Ciénega de Santa Clara Comprehensive Monitoring Program. Water Quality. National Institute of Ecology and Climate Change, 13-15. http://www2.inecc.gob.mx/publicaciones/libros/612/calidad.pdf

[5] NAWACO (2015) Quality Indicators WATER.National Water Commission. http://www.conagua.gob.mx/Contenido.aspx?n1=3\&n2=63\&n3=98\&n4=98

[6] Johnson, D.L., Ambrose, S.H., Bassett, T.J., Bowen, M.L., Crummey, D.E., Isaacson, J.S., Johnson, D.N., Lamb, P., Saul, M. and Winter-Nelson, A.E. (1997) Meanings of Environmental Terms. Journal of Environmental Quality, 26, 
581-589. http://dx.doi.org/10.2134/jeq1997.00472425002600030002x

[7] UN (2009) The Development of Water Resources in the World: Water in a Changing World. 3rd Report of the United Nations. http://www.un.org/spanish/waterforlifedecade/water_cities.shtml

[8] UN (2010) UN-Water Statement on Water Quality. http://www.unwater.org/downloads/unw_wwd_statement1.pdf

[9] UN (2010) Water for Sustainable Urban Human Settlements. Nota Informativa. WWAP, ONU-Hábitat.

[10] MRU (2015) Microbial Ecology Manual. Mayagüez Campus, University of Puerto Rico. http://www.uprm.edu/biology/profs/massol/manual/

[11] NAPE-CSC (2007) Eutrophication of Aquatic Ecosystems: Causes, Consequences and Strategies for Conservation and Rehabilitation. National Administration of Public Education-Council Steering Central. Teachers Regional Center South, Home Atlantis, Faculty of Science, University of Uruguay. http://imasd.fcien.edu.uy/difusion/educamb/propuestas/red/curso_2007/cartillas/tematicas/OD.pdf

[12] Moura de Moraes, A., Morante Trigoso, F. and Fedrizzi, M. (2011) The Problem of Obtaining Drinking Water in the Brazilian Semiarid Region Using Photovoltaic Systems for Water Pumping. Advances in Renewable Energy and Environment, 15, 97-104.

[13] Romero, M. (2010) Photovoltaic Solar Energy. Ed. Ceac Grupo Planeta.

[14] NMX-AA-012-SCFI-2001 (2001) Water Analysis-Determination of Dissolved Oxygen in Natural Water, Wastewater and Treated Wastewater-Test Method. Official Mexican Standard, Oficial Journal.

[15] MLMP (2011) MetropolitanLand Management Program of Altamira-Ciudad Madero, Tampico. http://www.imeplansurdetamaulipas.gob.mx/Pdf_POTMunicipales/POT\%20Zona\%20Metropolitana.pdf

[16] NISG (2015) Population Census 2010. National Institute of Statistics and Geography. http://www3.inegi.org.mx/sistemas/mexicocifras/default.aspx?e=28

[17] INEGI (2009) Prontuario de información geográfica municipal de los Estados Unidos Mexicanos. Tampico, Tamaulipas. Clave geoestadística 28038. Instituto Nacional de Estadistica y Geografia. http://www3.inegi.org.mx/sistemas/mexicocifras/datos-geograficos/28/28038.pdf

[18] Juárez, R. (1998) Preliminary Analysis of Hydrodynamics of the Laguna del Carpintero. Thesis, University of Tamaulipas, Mexico.

[19] EPA (1986) Quality Criteria for Water 1986. U.S. Environmental Protection Agency, Office of Water Regulations and Standards, 440/5-86-001, Washington DC.

[20] EPA (1976) Quality Criteria for Water. U.S. Environmental Protection Agency, Washington DC.

[21] Bain, M.B. and Stevenson, N.J. (1999) Aquatic Habitat Assessment: Common Methods. American Fisheries Society, Bethesda, Maryland.

[22] Marsilio, A. (2010) Dissolved Oxygen Meter Microprocessor HI 2400. Manual de Instructions Hanna Instruments.

[23] Marín, R. (2003) Physical Chemistry and Microbiology of Aquatic Environments, Treatment and Control of Water. Ed. Díaz de Santos S.A. 